\title{
Analisis faktor yang berhubungan dengan kemampuan pasien diabetes mellitus dalam melakukan deteksi episode hipoglikemia
}

\author{
Eka Yudha Chrisanto', Sapti Ayubbana², Yola Anjani ${ }^{3 *}$
}

1DIII Keperawatan Universitas Malahayati, Bandar Lampung.Email: yudhachrisanto88@gmail.com

2Akademi Keperawatan Dharma Wacana Metro. Email: Sapti.ayubbana@gmail.com

3Program Studi IImu Keperawatan, Fakultas Kedokteran, Universitas Malahayati, Bandar Lampung

*Email: yolaanjani07@gmail.com

\section{Abstract \\ Detection of hypoglycemia by adult with diabetes mellitus.}

Background : The increasing prevalence of people with diabetes mellitus occurs every year along with the increasing prosperity of a country, especially in developing countries because the wrong lifestyle changes can cause obesity which is one of the risk factors for diabetes.

Purpose: Know factors that are related to Detection of hypoglycemia by adult with diabetes mellitus.

Method: This is a descriptive correlational study, a cross sectional research design. The population in this study was the number of patients with diabetes mellitus of 40 respondents. The sample technique used was accidental sampling, research instruments using a questionnaire, with data analysis namely the chi square test.

Results: Finding that there was no relationship of age ( $p$-value 0.071$)$ and availability of glucometer with ( $p$-value 0.052 ), there was a relationship with education ( $p$-value 0.026 ), duration of suffering of DM ( $p$-value 0.016 ), there is a relationship of gender with ( $p$-value 0.010 ), there is a relationship of knowledge ( $p$-value 0.008$)$. In detecting episodes of hypoglycemia ( $p$-value 0.052 ).

Conclusion: Several factors in detecting episodes of hypoglycemia in the context of nursing care are closely related such as; education, duration of diabetes, gender, and knowledge.

Keywords: Detection; Hypoglycemia; Adult; Diabetes mellitus.

Pendahuluan: Hipoglikemia terjadi karena peningkatan insulin dalam darah dan penurunan kadar glukosa. Terapi insulin yang tidak adekuat disebabkan oleh ketidaksempurnaan terapi insulin saat ini, dimana pemberian insulin masih belum sepenuhnya dapat menirukan (mimicking) pola sekresi insulin yang fisiologis. Hipoglikemia diabetik lebih sering terjadi pada pasien diabetes tipe 1, namun dapat juga terjadi pada pasien diabetes tipe 2 yang mendapatkan terapi insulin, dan merupakan faktor penghambat utama dalam penanganan diabetes mellitus.

Tujuan: Mengetahui faktor faktor yang berhubungan dengan kemampuan pasien diabetes mellitus dalam melakukan deteksi episode hipoglikemia dalam konteks asuhan keperawatan .

Metode: Penelitian dilakukan pada Juli 2019 dengan menggunakan metode Cross Sectional. Melibatkan 40 responden di Poli Penyakit Dalam Rumah Sakit Umum Daerah Dr. H. Abdul Moeloek Propinsi Lampung. Pengumpulan data dilakukan dengan cara wawancara langsung menggunakan kuisioner pengetahuan tentang Hipoglikemia untuk menilai tingkat pengetahuan dan kuisioner kemampuan deteksi hipoglikemia untuk menilai kemampuan melakukakn deteksi episode hipoglikemia pada responden.

Hasil : Tidak terdapat hubungan usia ( $p$-value 0.071) dan ketersediaan alat glukometer dengan ( $p$-value 0.052), terdapat hubungan pendidikan dengan ( $p$-value 0,026), lama menderita DM dengan ( $p$-value 0,016$)$, jenis kelamin dengan ( $p$-value 0,010), dan pengetahuan $(p$-value 0,008$)$ dalam melakukan deteksi episode hipoglikemia dalam konteks asuhan keperawatan ( $p$-value 0,052).

Simpulan: Beberapa faktor dalam melakukan deteksi episode hipoglikemia dalam konteks asuhan keperawatan sangat erat berhubungan seperti; pendidikan, lama menderita DM, jenis kelamin, dan pengetahuan

Kata Kunci: Diabetes mellitus; Deteksi; Hipoglikemia; Asuhan Keperawatan 
Analisis faktor yang berhubungan dengan kemampuan pasien diabetes mellitus dalam melakukan deteksi episode hipoglikemia

\section{PENDAHULUAN}

Diabetes merupakan penyebab kematian ke-6 di dunia. Pada tahun 2015, sekitar 415 juta orang di seluruh dunia diperkirakan menderita diabetes melitus. Sedangkan pada tahun 2017, penderita diabetes melitus meningkat menjadi 425 juta diseluruh dunia. Jumlah terbesar orang dengan diabetes melitus yaitu berada di wilayah Pasifik Barat 159 juta dan Asia Tenggara 82 juta. China menjadi negara dengan penderita diabetes melitus terbanyak di dunia dengan 114 juta penderita, kemudian di ikuti oleh India 72,9 juta, lalu Amerika serikat 30,1 juta, kemudian Brazil 12,5 juta dan Mexico 12 juta penderita. Indonesia menduduki peringkat ke-enam untuk penderita diabetes melitus terbanyak di dunia dengan jumlah 10,3 juta penderita (International Diabetes Federation, 2017).

Pada tahun 2014 persentase penderita DM tipe II sejumlah $1,5 \%$ per 100.000 atau sebanyak 5.560 , dan berdasarkan hasil observasi catatan data pada saat pra survey yang diperoleh dari ruang rawat jalan dan rawat inap RSUD. Dr. H. Abdul Moeloek Provinsi Lampung, diketahui bahwa pada tahun 2017 dari jumlah penderita diabetes melitus sebesar 473 dan sebanyak 76 orang mengalami hipoglikemia, dan meningkat pada tahun 2018 jumlah penderita Diabetes Melitus 513 orang dengan mengalami hipoglikemia menjadi 89 orang pada tahun 2018 orang (Anggraeni, \& Alfarisi, 2018).

Hipoglikemia terjadi karena peningkatan insulin dalam darah dan penurunan kadar glukosa. Terapi insulin yang tidak adekuat disebabkan oleh ketidaksempurnaan terapi insulin saat ini, dimana pemberian insulin masih belum sepenuhnya dapat menirukan (mimicking) pola sekresi insulin yang fisiologis (Sudoyo, Setiyohadi, Alwi, Simadibrata, \& Setiati, 2015). Hipoglikemia diabetik lebih sering terjadi pada pasien diabetes tipe 1 , namun dapat juga terjadi pada pasien diabetes tipe 2 yang mendapatkan terapi insulin, dan merupakan faktor penghambat utama dalam penanganan diabetes mellitus (Safitri, Kadrianti, \& Ismail, 2014).

Pengenalan gejala awal hipoglikemia sebagai respon fisiologis penurunan glukosa darah dan pemantauan gula darah secara rutin merupakan upaya deteksi dini hipoglikemia dalam pencegahan hipoglikemia yang lebih berat. Monitoring kadar gula darah secara mandiri (Self Monitoring of Blood Glucose ( SMBG) merupakan pendekatan yang tepat dalam mencegah hipoglikemia, dimana pasien dapat mengatur terapinya untuk mengendalikan kadar glukosa secara optimal dan dapat mengurangi komplikasi diabetes jangka panjang (Supadi, 2011).

\section{METODE PENELITIAN}

Jenis penelitian kuantitatif dengan populasi pasien Diabetes Melitus yang pernah mengalami Hipoglikemia sebanyak 40 responden. Lakasinya di Ruang Poli Penyakit dalam Rumah Sakit Umum Daerah Dr. H. Abdul Moeloek Propinsi Lampung. Metode yang digunakan Acidental sampling dan dilakukan selama bulan Juli 2019. Peneliti mendapatkan surat layak etik No. Surat 322/EC/KEP-UNMAL///2019. Adapun variable independen meliputi; Usia, Tingkat Pendidikan, Lama/durasi menderita DM, Jenis Kelamin, Pengetahuan, dan ketersediaannya alat pengukur glukosa secara mandiri (Glukometer). Variabel dependennya kemampuan deteksi episode Hipogliemia.

Alat ukurnya menggunakan instrumen berupa kuesioner 1, yaitu kuisioner Demografi Responden dengan jumlah pernyataan sebanyak 5 buah. Kuisioner 2 yaitu status diabetes melitus dengan jumlah pertanyaan 3 buah, Kuisioner tentang pengetahuan hipoglikemia berjumlah 15 buah pertanyaan, Kuisioner 4 tentang kemampuan deteksi episode hipogliemia berjumlah 14 buah pertanyaan.

Eka Yudha Chrisanto' DIII Keperawatan Universitas Malahayati, Bandar Lampung Email: yudhachrisanto88@gmail.com Sapti Ayubbana ${ }^{2}$ Akademi Keperawatan Dharma Wacana Metro. Email: Sapti.ayubbana@gmail.com Yola Anjani ${ }^{3 *}$ Program Studi llmu Keperawatan, Fakultas Kedokteran, Universitas Malahayati, Bandar Lampung

*Email: yolaanjani07@gmail.com 
HASIL

Tabel 1. Distribusi Karakteristik Responden $\mathrm{N}=40$

\begin{tabular}{|c|c|c|}
\hline Variabel & Frekuensi (f) & Persentase (\%) \\
\hline $\begin{array}{l}\text { Usia } \\
-\quad \geq 40 \text { Tahun } \\
-<40 \text { Tahun }\end{array}$ & $\begin{array}{l}25 \\
15\end{array}$ & $\begin{array}{l}62.5 \\
75.5\end{array}$ \\
\hline $\begin{array}{l}\text { Tingkat Pendidikan } \\
\text { - Rendah (SD/SLTP) } \\
\text { - Tinggi (SLTA/PT) }\end{array}$ & $\begin{array}{l}20 \\
20\end{array}$ & $\begin{array}{l}50.0 \\
50.0\end{array}$ \\
\hline $\begin{array}{l}\text { Lama atau durasi menderita DM } \\
-<6 \text { Tahun } \\
-\geq 6 \text { Tahun }\end{array}$ & $\begin{array}{l}16 \\
24\end{array}$ & $\begin{array}{l}40.0 \\
60.0\end{array}$ \\
\hline $\begin{array}{l}\text { Jenis Kelamin } \\
\text { - Perempuan } \\
\text { - Laki-laki }\end{array}$ & $\begin{array}{l}19 \\
21\end{array}$ & $\begin{array}{l}47.5 \\
52.5\end{array}$ \\
\hline $\begin{array}{l}\text { Pengetahuan } \\
\text { - Buruk } \\
\text { - Baik }\end{array}$ & $\begin{array}{l}17 \\
23\end{array}$ & $\begin{array}{l}42.5 \\
57.5\end{array}$ \\
\hline 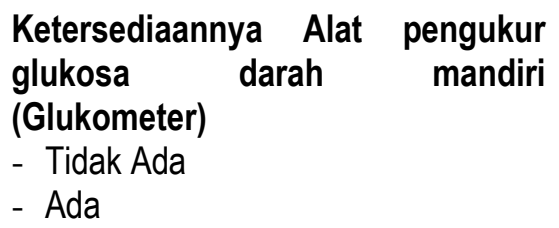 & $\begin{array}{l}19 \\
21\end{array}$ & $\begin{array}{l}47.5 \\
52.5\end{array}$ \\
\hline $\begin{array}{l}\text { Kemampuan Melakukan Deteksi } \\
\text { Episode Hipoglikemia } \\
\text { - Tidak mampu } \\
\text { - Mampu }\end{array}$ & $\begin{array}{l}22 \\
18\end{array}$ & $\begin{array}{l}55.0 \\
45.0\end{array}$ \\
\hline
\end{tabular}

Berdasarkan tabel 1 Karakteristik responden berdasarkan usia, pendidikan, Lama atau durasi menderita DM, jenis kelamin, Pengetahuan, Ketersediaannya alat glukometer, kemampuan melakukan deteksi episode hipoglikemia. Faktor usia terbanyak adalah usia $>40$ tahun sebesar $62,5 \%$. Pendidikan responden rata rata seimbang yaitu pendidikan rendah sebesar $50 \%$. Lama durasi menderita DM terbanyak $\geq 6$ tahun yaitu sebesar $60 \%$. Dari jenis kelamin, Laki-laki mendominasi dengan jumlah $52,5 \%$. Pengetahuan paling banyak baik sebesar $57,5 \%$. ketersediaannya alat glukometer, rata-rata responden mempunyai alat glukometer sebanyak $52 \%$. Kemampuan deteksi episode hipoglikemia responden kategori tidak mampu sebesar $55.0 \%$.

Eka Yudha Chrisanto' DIII Keperawatan Universitas Malahayati, Bandar Lampung. Email: yudhachrisanto88@gmail.com Sapti Ayubbana² Akademi Keperawatan Dharma Wacana Metro. Email: Sapti.ayubbana@gmail.com Yola Anjani* ${ }^{3 *}$ Program Studi llmu Keperawatan, Fakultas Kedokteran, Universitas Malahayati, Bandar Lampung *Email: yolaanjani07@gmail.com 
Analisis faktor yang berhubungan dengan kemampuan pasien diabetes mellitus dalam melakukan deteksi episode hipoglikemia

Tabel 2. Faktor-Faktor Yang Berhubungan Dengan Kemampuan Deteksi Episode Hipoglikemia $\mathbf{N}=\mathbf{4 0}$

\begin{tabular}{|c|c|c|c|c|c|c|c|c|}
\hline \multirow{3}{*}{ Variabel } & \multicolumn{4}{|c|}{$\begin{array}{c}\text { Kemampuan Deteksi Episode } \\
\text { Hipoglikemia }\end{array}$} & \multirow{2}{*}{\multicolumn{2}{|c|}{ Total }} & \multirow[t]{3}{*}{$p$-Value } & \multirow[t]{3}{*}{ OR (Cl 95\%) } \\
\hline & \multicolumn{2}{|c|}{ Tidak mampu } & \multicolumn{2}{|c|}{ Mampu } & & & & \\
\hline & $\mathrm{n}$ & $\%$ & $\mathrm{n}$ & $\%$ & $\mathrm{~N}$ & $\%$ & & \\
\hline \multicolumn{9}{|l|}{ Usia } \\
\hline$\geq 40$ Tahun & 17 & 42,5 & 8 & 20,0 & 25 & 62,5 & 0,071 & \\
\hline$<40$ Tahun & 5 & 12,5 & 10 & 25,0 & 15 & 37,5 & & \\
\hline \multicolumn{9}{|l|}{ Pendidikan } \\
\hline Rendah & 15 & 37,5 & 5 & 12.5 & 20 & 50 & 0,026 & $5,57(1,4-21,8)$ \\
\hline Tinggi & 7 & 17.5 & 13 & 32.5 & 20 & 50 & & \\
\hline \multicolumn{9}{|l|}{ Lama menderita } \\
\hline \multicolumn{9}{|l|}{ DM } \\
\hline$<6$ Tahun & 13 & 32.5 & 3 & 7.5 & 16 & 40 & 0,016 & $7,2(1,6-32,4)$ \\
\hline$\geq 6$ Tahun & 9 & 22.5 & 15 & 37.5 & 24 & 60 & & \\
\hline \multicolumn{9}{|l|}{ Jenis kelamin } \\
\hline Perempuan & 15 & 37.5 & 4 & 10 & 19 & 47.5 & 0,010 & $7,5(1,8-31,3)$ \\
\hline Laki-laki & 7 & 17.5 & 14 & 35 & 21 & 52.5 & & \\
\hline \multicolumn{9}{|l|}{ Pengetahuan } \\
\hline Buruk & 14 & 35 & 3 & 7.5 & 17 & 42.5 & 0,008 & $8,6(1,9-39,8)$ \\
\hline Baik & 8 & 20 & 15 & 37.5 & 23 & 57.5 & & \\
\hline \multicolumn{9}{|l|}{$\begin{array}{l}\text { Ketersediaan } \\
\text { glukometer }\end{array}$} \\
\hline Tidak ada & 14 & 35 & 5 & 12.5 & 19 & 47.5 & 0,052 & \\
\hline Ada & 8 & 20 & 13 & 32.5 & 21 & 52.5 & & \\
\hline
\end{tabular}

Berdasarkan tabel diatas responden yang berusia $\geq 40$ tahun sebanyak 17 responden $(68,0 \%)$ dan dari 15 responden dengan usia $<40$ tahun, sebanyak 5 responden $(33,0 \%)$ dalam kategori tidak mampu dalam mendeteksi episode hipoglikemia. Hasil uji chi square didapatkan nilai $p$-value 0,071 , artinya lebih besar dibandingkan dengan nilai alpha $(0,071>0,05)$. Dengan demikian dapat disimpulkan secara statistik dengan derajat kepercayaan $95 \%$, diyakini tidak ada hubungan usia dalam kemampuan melakukan deteksi episode hipoglikemia dalam konteks asuhan keperawatan.

Berdasarkan tingkat pendidikan bahwa berpendidikan rendah sebanyak 15 responden $(75,0 \%)$ dan dari 20 responden dengan pendidikan tinggi, sebanyak 7 responden $(35,0 \%)$ dalam kategori tidak mampu dalam mendeteksi episode hipoglikemia. Hasil uji chi square didapatkan nilai $p$ value 0,026 , artinya lebih kecil dibandingkan dengan nilai alpha $(0,026<0,05)$.

Berdasarkan lamanya menderita DM $<6$ Tahun sebanyak 13 responden $(81,3 \%)$ dan dari 24 responden dengan lama menderita $\mathrm{DM}>6$ Tahun, sebanyak 9 responden $(37,5 \%)$ dalam kategori tidak mampu dalam mendeteksi episode hipoglikemia. Hasil uji chi square didapatkan nilai $p$ value 0,016 , artinya lebih kecil dibandingkan dengan nilai alpha $(0,016<0,05)$.

Berdasarkan jenis kelamin perempuan sebanyak 15 responden $(78,9 \%)$ dan dari 21 responden dengan jenis kelamin laki-laki, sebanyak 7 responden $(33,3 \%)$ dalam kategori tidak mampu dalam mendeteksi episode hipoglikemia. Hasil uji chi square didapatkan nilai $p$

Eka Yudha Chrisanto' DIII Keperawatan Universitas Malahayati, Bandar Lampung Email: yudhachrisanto88@gmail.com Sapti Ayubbana ${ }^{2}$ Akademi Keperawatan Dharma Wacana Metro. Email: Sapti.ayubbana@gmail.com Yola Anjani ${ }^{3 *}$ Program Studi llmu Keperawatan, Fakultas Kedokteran, Universitas Malahayati, Bandar Lampung

*Email: yolaanjani07@gmail.com 
Analisis faktor yang berhubungan dengan kemampuan pasien diabetes mellitus dalam melakukan deteksi episode hipoglikemia

value 0,010 , artinya lebih kecil dibandingkan dengan nilai alpha $(0,010<0,05)$.

Berdasarkan pengetahuan responden kategori buruk sebanyak 14 responden $(82,4 \%)$ dan dari 23 responden dengan pengetahuan baik, sebanyak 8 responden $(34,8 \%)$ dalam kategori tidak mampu dalam mendeteksi episode hipoglikemia. Hasil uji chi square didapatkan nilai $p$ value 0,008 , artinya lebih kecil dibandingkan dengan nilai alpha $(0,008<$ 0,05).

Berdasarkan ketersediaan glukometer sebanyak 14 responden $(73,7 \%)$ dan dari 23 responden dengan memiliki glukometer, sebanyak 8 responden $(38,1 \%)$ dalam kategori tidak mampu dalam mendeteksi episode hipoglikemia. Hasil uji chi square didapatkan nilai $p$ value 0,052 , artinya lebih kecil dibandingkan dengan nilai alpha $(0,052>$ 0,05)

\section{PEMBAHASAN \\ Usia dalam kemampuan melakukan deteksi episode hipoglikemia}

Berdasarkan hasil penelitian menunjukkan bahwa lebih dari separuh responden berusia $\geq 40$ tahun yaitu sebanyak 25 responden (62,5\%). Seseorang yang berumur diatas 46 tahun memiliki peningkatan resiko terhadap terjadinya DM dan intoleransi glukosa yang di sebabkan oleh faktor degeneratif yaitu menurunya fungsi tubuh, khususnya kemampuan dari sel $\beta$ dalam memproduksi insulin untuk memetabolisme glukosa. kemungkinan lain terjadinya diabetes ini adalah karena sel-sel jaringan tubuh tidak peka atau resisten terhadap insulin karena faktor usia (Betteng, 2014).

Usia merupakan salah satu faktor resikoyang dapat menentukan keparahan dan prognsis penyakit DM pada lansia berkaitan erat dengan penurunan fisiologi tubuh, penggunaan obat yang beragam dan peningkatan masuk rumah sakit. Semakin muda usia pasien, maka semakin meningkat kemampuan melakukan penatalaksanaan hipoglikemi, bahwa umur terbanyak yang menderita diabetes melitus adalah umur $\geq 40$ tahun yaitu sebanyak 47 kasus $(47.5 \%)$ ( Safitri, Kadrianti, \& Ismail, 2014).

Berdasarkan hasil penelitian nilai $p$ value 0,071 , artinya lebih besar dibandingkan dengan nilai alpha $(0,071>0,05)$. Dengan demikian dapat disimpulkan secara statistik dengan derajat kepercayaan $95 \%$, diyakini tidak ada hubungan usia dalam melakukan deteksi episode hipoglikemia dalam konteks asuhan keperawatan.

Hasil penelitian ini sejalan dengan teori bahwa perilaku lansia lebih memiliki pengalaman keterpaparan stimulus berupa gejala hipoglikemi sehingga timbul upaya intervensi terhadap gejala hipoglikei dan antisipasi mencegah hipoglikemia berikutnya. Hal ini sesuai dengan teori perubahan perilaku stimulus organisme relaksi (SOR), bahwa perubahan perilaku terjadi akibat sesorang mengalami stimulus secara terus menerus sehingga perubahan perilaku semakin mudah (Notoatmodjo, 2012; Gaol, 2016).

\section{Tingkat pendidikan dalam kemampuan melakukan deteksi episode hipoglikemia}

Berdasarkan hasil penelitian didapati bahwa responden sebagian besar pendidikan rendah sebanyak 20 responden $(50,0 \%)$ Tingkat pendidikan merupakan salah satu faktor yang menetukan terhadap terjadinya perubahan perilaku. Tingkat pendidikan juga sangat menentukan kemampuan klien untuk memahami tentang kondisi kesehatannya. Individu yang memiliki tingkat pendidikan rendah akan mengalami kesulitan untuk mengenal masalah kesehatan serta memahami panduan penanganan penyakit dibandingkan dengan individu yang mempunyai tingkat pendidikan yang baik akan meningkatkan pengenalan klien terhadap faktor yang mempengaruhi kesehatannya dan efek jangka panjang terhadap kesehatannya tersebut. Selain itu tingkat pendidikan juga berpengaruh terhadap kepatuhan seseorang terhadap manajemen pengobatan yang dijalaninya. Dalam penelitian membagi tingkat pendidikan berdasarkan tingkat pendidikan rendah (SD sampai SMP) dan tingkat pendidikan tinggi (SMA sampai Perguruan Tinggi) (Shufyani, Wahyuni, \& Armal, 2017). Tingkat pendidikan sampel dapat berhubungan dengan kemampuan dalam menerima informasi-informasi kesehatan khususnya tentang diabetes melitus termasuk perawatan kesehatan. Orang yang tingkat pendidikannya tinggi biasanya akan memiliki banyak pengetahuan tentang kesehatan. Dengan adanya pengetahuan tersebut orang akan memiliki kesadaran dalam menjaga kesehatannya (Irawan, 2010; Trisnawati, \& Setyorogo, 2013).

Eka Yudha Chrisanto' DIIl Keperawatan Universitas Malahayati, Bandar Lampung Email: yudhachrisanto88@gmail.com Sapti Ayubbana ${ }^{2}$ Akademi Keperawatan Dharma Wacana Metro. Email: Sapti.ayubbana@gmail.com Yola Anjani ${ }^{3 *}$ Program Studi llmu Keperawatan, Fakultas Kedokteran, Universitas Malahayati, Bandar Lampung *Email: yolaanjani07@gmail.com 
Analisis faktor yang berhubungan dengan kemampuan pasien diabetes mellitus dalam melakukan deteksi episode hipoglikemia

Berdasarkan hasil penelitian didapatkan nilai $p$ value 0,026 , artinya lebih kecil dibandingkan dengan nilai alpha $(0,026<0,05)$. Dengan demikian dapat disimpulkan secara statistik dengan derajat kepercayaan 95\%, diyakini ada hubungan pendidikan dalam melakukan deteksi episode hipoglikemia dalam konteks asuhan keperawatan. Sedangkan hasil uji OR diperoleh nilai 5,57 (Cl $95 \%$ 1,4-21,8), artinya responden dengan pendidikan rendah berpeluang 5,57 kali lebih besar untuk tidak mampu dalam mendeteksi episode hipoglikemia dibandingkan responden dengan pendidikan tinggi.

Tingkat pendidikan merupakan salah satu faktor yang menetukan terhadap terjadinya perubahan perilaku.Tingkat pendidikan juga sangat menentukan kemampuan klien untuk memahami tentang kondisi kesehatannya. Individu yang memiliki tingkat pendidikan rendah akan mengalami kesulitan untuk mengenal masalah kesehatan serta memahami panduan penanganan penyakit dibandingkan dengan individu yang mempunyai tingkat pendidikan yang baik akan meningkatkan pengenalan klien terhadap faktor yang mempengaruhi kesehatannya dan efek jangka panjang terhadap kesehatannya tersebut. Selain itu tingkat pendidikan juga berpengaruh terhadap kepatuhan seseorang terhadap manajemen pengobatan yang dijalaninya. Dalam penelitian membagi tingkat pendidikan berdasarkan tingkat pendidikan rendah (SD sampai SMP) dan tingkat pendidikan tinggi (SMA sampai Perguruan Tinggi) (Shufyani, Wahyuni, \& Armal, 2017; Budiman, Khambri, \& Bachtiar, 2013).

\section{Lama menderita DM dalam kemampuan melakukan deteksi episode hipoglikemia}

Berdasarkan Hasil penelitian menunjukkan bahwa responden sebagian besar lama menderita DM > 6 tahun sebanyak 24 responden $(60,0 \%)$.Lama durasi diabetes ini berkaitan dengan resiko kejadian dan frekuensi diabetes, dimana episode hipoglikemia yang berulang dapat menimbulkan kerusakan pada kerusakan glukosensitif. Pasien diabetes yang lama memiliki kecenderungan berkurangnya intensitas keluhan otonomik atau bahkan menghilang disebabkan oleh kegagalan yang progresif aktivasi sistem saraf otonomik, sehingga sering terjadi hipoglikemia yang tidak disadari/unawareness (Brunner, Smeltzer, \& Suddarth, 2010; Sudoyo, Setiyohadi, Alwi, Simadibrata, \& Setiati, 2015).

Pasien yang menderita DM dan sering mengalami episode hipoglikemia cenderung memiliki kemampuan untuk melakukan identifikasi terhadap gejala hipoglikemia yang dirasakan, selanjutnya akan melawan atau melakukan upaya pencegahan dan semakin lama menderita kemampuan yang dimiliki akan lebih banyak (Sutawardana, \& Waluyo, 2016; Tombokan, 2015). Pasien yang menderita diabetes lebih dari 6 tahun memiliki kemampuan deteksi episode hipoglikemia lebih besar $(41,7 \%)$ dibandingkan dengan yang menderita 3 bulan sampai 6 tahun (38.5\%) (Supadi, 2017).

Hasil penelitian didapatkan nilai $p$ value 0,016 , artinya lebih kecil dibandingkan dengan nilai alpha $(0,016<0,05)$. Dengan demikian dapat disimpulkan secara statistik dengan derajat kepercayaan $95 \%$, diyakini ada hubungan lama menderita DM dalam melakukan deteksi episode hipoglikemia dalam konteks asuhan keperawatan. Sedangkan hasil uji OR diperoleh nilai 7,2 (Cl 95\% 1,6-32,4), artinya responden dengan lama menderita $\mathrm{DM}<6$ Tahun berpeluang 7,2 kali lebih besar untuk tidak mampu dalam mendeteksi episode hipoglikemia dibandingkan responden dengan lama menderita DM $>6$ Tahun.

Pasien DM yang telah berlangsung lama memiliki kecenderungan lebih sering mengalami episode hipoglikemia, sehingga pengalaman terpapar hipoglikemi tersebut merupakan stimulus terhadap tindakan deteksi. Menurut teori perilaku sakit mechanics menjelaskan bahwa seseorang yang sering mengalami kondisi sakit atau merasakan adanya gejala sakit memiliki kecenderungan untuk berperilaku dengan menaruh perhatian terhadap gejala-gejala pada dirinya dan kemudian mencari pertolongan (Notoatmodjo, 2012).

\section{Jenis kelamin dalam kemampuan melakukan deteksi episode hipoglikemia}

Berdasarkan hasil penelitian menunjukkan bahwa responden sebagian besar berjenis kelamin laki-laki sebanyak 21 responden (52.5\%). Pendapat lain tentang risiko kejadian diabetes mellitus pada laki-laki yang lebih banyak karena risiko dari adanya distribusi lemak tubuh. Pada

Eka Yudha Chrisanto' DIIl Keperawatan Universitas Malahayati, Bandar Lampung Email: yudhachrisanto88@gmail.com Sapti Ayubbana ${ }^{2}$ Akademi Keperawatan Dharma Wacana Metro. Email: Sapti.ayubbana@gmail.com Yola Anjani ${ }^{3 *}$ Program Studi llmu Keperawatan, Fakultas Kedokteran, Universitas Malahayati, Bandar Lampung *Email: yolaanjani07@gmail.com 
Analisis faktor yang berhubungan dengan kemampuan pasien diabetes mellitus dalam melakukan deteksi episode hipoglikemia

laki-laki, penumpukan lemak terkonsentrasi di sekitar perut sehingga memicu obesitas sentral yang lebih berisiko memicu gangguan metabolisme (Akhsyari, \& Faizah, 2017).

Hasil penelitian didapatkan nilai $p$ value 0,010 , artinya lebih kecil dibandingkan dengan nilai alpha $(0,010<0,05)$. Dengan demikian dapat disimpulkan secara statistik dengan derajat kepercayaan $95 \%$, diyakini ada hubungan jenis kelamin dalam melakukan deteksi episode hipoglikemia dalam konteks asuhan keperawatan. Sedangkan hasil uji OR diperoleh nilai 7,5 (Cl 95\% 1,8-31,3), artinya responden dengan jenis kelamin perempuan berpeluang 7,5 kali lebih besar untuk tidak mampu dalam mendeteksi episode hipoglikemia dibandingkan responden dengan jenis kelamin lakilaki.

Perempuan dan laki-laki menurut beberapa penelitian mengatakan tidak ada hubungan antara perempuan dan laki-laki dalam kemampuan mendeteksi episode hipoglikemia (Supadi, 2017). Namun peneliti luar negeri menyimpulkan perempuan cenderung resiko memiliki hipoglikemia lebih besar dari pria. Pada keadaan glukosa normal kadar epineprin dan glukagon menunjukkan level yang seimbang antara perempuan dan lakilaki pada keadaan hipoglikemia terjadi peningkatan kadar glukagon dan epineprin lebih besar pria dibanding wanita, sehingga disimpulkan bahwa laki-laki memiliki respon yang lebih cepat.

\section{Tingkat pengetahuan dalam kemampuan melakukan deteksi episode hipoglikemia}

Hasil penelitian menunjukkan bahwa responden sebagian besar memiliki pengetahuan baik sebanyak 23 responden (57.5\%). Penelitian ini sejalan dengan penelitian sebelumnya bahwa hanya $13 \%$ pasien diabetes yang memiliki pengetahuan tentang hipoglikemia. Hasil penelitian ini menunjukkan bahwa hampir separuh responden tidak memiliki pengetahuan tentang hipoglikemi, sehingga perlu dilakukan pengkajian tentang faktor yang menyebabkan pasien diabetes tidak mengetahui komplikasi akut yang sering terjadi yaitu hipoglikemia. Kurangnya pasien diabetes mengenal gejala hipoglikemia disebabkan oleh kurangnya informasi yang diberikan oleh tenaga kesehatan pada saat pasien mulai terdiagnosa diabetes (Nita, Yuda, \& Nugraheni, 2012)
Hasil penelitian didapatkan nilai $p$ value 0,008 , artinya lebih kecil dibandingkan dengan nilai alpha $(0,008<0,05)$. Dengan demikian dapat disimpulkan secara statistik dengan derajat kepercayaan $95 \%$, diyakini ada hubungan pengetahuan dalam kemampuan melakukan deteksi episode hipoglikemia dalam konteks asuhan keperawatan. Sedangkan hasil uji OR diperoleh nilai 8,6 (Cl 95\% 1,9-39,8), artinya responden dengan kurang pengetahuan berpeluang 8,6 kali lebih besar untuk tidak mampu dalam mendeteksi episode hipoglikemia dibandingkan responden dengan pengetahuan baik.

Pengetahuan merupakan faktor yang mempengaruhi perilaku seseorang terhadap suatu objek, sehingga kemampuan deteksi hipoglikemia juga masuk dalam kategori pengetahuan karena merupakan proses terbentunya perilaku yang digolongkan dalam 3 domain perilaku yaitu kognitif (cognitive), afektif (affective)dan psikomotor (psychomotor). Dalam hal ini pengetahuan masuk dalam domain kognitif yang berkaitan dengan pembentukan tindakan seseorang. Domain afektif berkaitan dengan sikap yang merupakan reaksi atau respon yang tertutup dan domain psikomotor yang berkaitan dengan tindakan merupakan gabungan dari pengetahuan dan sikap terhadap objek (Bloom, 1979; Notoatmodjo, 2012). Perilaku seseorang sangat dipengaruhi oleh faktor pengetahuan, dan pengetahuan itu sendiri dipengaruhi oleh dua faktor yaitu faktor internal seperti; pendidikan, pekerjaan, umur dan faktor eksternal seperti; faktor lingkungan dan sosial budaya (Pribadi, Trismiyana, \& Maria, 2017).

\section{Ketersediaan glukometer dalam kemampuan melakukan deteksi episode hipoglikemia}

Hasil penelitian menunjukkan bahwa responden sebagian besar memiliki glukometer sebanyak 21 responden (52.5\%). Kepatuhan pasien DM dalam penatalaksanaan pengobatan yang berada dirumah sangat penting, karena pengendalian kadar glukosa yang baik akan mencegah timbulnya komplikasi. Penatalaksanaan diabetes sangat kompleks salah satunya penderita mampu merawat diri dengan mengendalikan kadar glukosamemiliki alat pantau cepat untuk mengontrol gula darah. Sebaiknya setiap pengecekan ditulis dan disampaikan kepada petugas kesehatan hasil dari guladarah sebagai

Eka Yudha Chrisanto' DIIl Keperawatan Universitas Malahayati, Bandar Lampung. Email: yudhachrisanto88@gmail.com Sapti Ayubbana ${ }^{2}$ Akademi Keperawatan Dharma Wacana Metro. Email: Sapti.ayubbana@gmail.com

Yola Anjani ${ }^{3 *}$ Program Studi llmu Keperawatan, Fakultas Kedokteran, Universitas Malahayati, Bandar Lampung

*Email: yolaanjani07@gmail.com 
Analisis faktor yang berhubungan dengan kemampuan pasien diabetes mellitus dalam melakukan deteksi episode hipoglikemia

gambaran pasien atas usaha pengontrolan glukosa normal dan sebagai langkah kelanjutan untuk pengobatan (Fatehi-Hassanabad, Chan, \& Furman, 2010). Ketersediaan glukometer merupakan faktor utama dalam SMBG, namun pada kenyataannya terdapat banyak pasien diabetes yang tidak memiliki glukometer karena berbagai hal, antara lain berkaitan dengan pembiayaan dan pengetahuan menggunakan glukometer tersebut. Sebuah penelitian menyatakan bahwa salah satu penghambat pelaksanaan SMBG adalah berkaitan dengan pembiayaan peralatan SMBG (SMBG equipment) bagi pasien diabetes (Adam, et al, 2003).

Hasil penelitian didapatkan nilai $p$ value 0,052 , artinya lebih kecil dibandingkan dengan nilai alpha $(0,052>0,05)$. Dengan demikian dapat disimpulkan secara statistik dengan derajat kepercayaan $95 \%$, diyakini tidak ada hubungan ketersediaan glukometer dalam melakukan deteksi episode hipoglikemia dalam konteks asuhan keperawatan.

Kepatuhan pasien DM dalam penatalaksanaan pengobatan yang berada dirumah sangat penting, karena pengendalian kadar glukosa yang baik akan mencegah timbulnya komplikasi. Penatalaksanaan diabetes sangat kompleks salah satunya penderita mampu merawat diri dengan mengendalikan kadar glukosa memiliki alat pantau cepat untuk mengontrol gula darah. Sebaiknya setiap pengecekan ditulis dan disampaikan kepada petugas kesehatan hasil dari gula darah sebagai gambaran pasien atas usaha pengontrolan glukosa normal dan sebagai langkah kelanjutan untuk pengobatan, berdasarkan kepemilikan alat glukometri pasien yang memiliki dan yang tidak memiliki alat glukometri menunujukkan kemampuan yang sama dalam mendeteksi episode hipoglikiemia sebesar 40\% (Fatehi, at al. 2010; Supadi, 2017).

\section{SIMPULAN}

Distribusi frekuensi responden berusia $>40$ tahun yaitu sebanyak 25 responden (62,5\%), berjenis kelamin laki-laki sebanyak 21 responden $(52.5 \%)$ dengan pendidikan rendah sebanyak 20 responden $(50,0 \%)$. Tidak ada hubungan usia dalam melakukan deteksi episode hipoglikemia dalam konteks asuhan keperawatan ( $p$ value 0,071 ). Ada hubungan pendidikan ( $p$ value 0,026 ), lamanya menderita DM ( $p$ value 0,016 ), jenis kelamin ( $p$ value 0,010$)$, pengetahuan ( $p$ value 0,008 ). Tidak ada hubungan ketersediaan glukometer ( $p$ value 0,052 ).

\section{SARAN}

Sebagai masukan untuk pelayanan kesehatan untuk meningkatkan tindakan keperawatan sesuai hasil penelitian yang berhubungan dengan faktorfaktor terkait. Peningkatan dalam penatalaksanaan hipoglikemia guna mencegah komplikasi yang lebih buruk dan deteksi dini bagi penderita secara mandiri. Penelitian ini merupakan salah satu bagian dari self care dalam asuhan keperawatan pasien hipoglikemia yaitu pengkajian keperawatan tentang faktor resiko hipoglikemia, sehingga dapat dikembangkan penelitian lebih lanjut, misalnya kemampuan self care tentang pencegahan dan penanganan hipoglikemia.

\section{DAFTAR PUSTAKA}

Akhsyari, F. Z., \& Faizah B, R. (2017). Karakteristik Pasien Diabetes Mellitus Di Rsud dr. Soehadi Prijonegoro Sragen Tahun 2015 (Doctoral dissertation, Universitas Muhammadiyah Surakarta).

Anggraeni, I., \& Alfarisi, R. (2018). Hubungan aktifitas fisik dengan kadar gula darah puasa pada penderita diabetes melitus tipe ii di rumah sakit umum daerah DR. H. Abdul Moeloek. Jurnal Dunia Kesmas, 7(3).

Betteng, R. (2014). Analisis faktor resiko penyebab terjadinya Diabetes Melitus tipe 2 pada wanita usia produktif Dipuskesmas Wawonasa. eBiomedik, 2(2).

Bloom, B. S. (1979). Taxonomy of Education Objectives the Classification Domain.

Brunner, L. S., Smeltzer, S. C. O., \& Suddarth, D. S. (2010). Brunner \& Suddarth's textbook of medical-surgical nursing; Vol. 1. Language, 27, 1114-2240p.

Eka Yudha Chrisanto' DIII Keperawatan Universitas Malahayati, Bandar Lampung Email: yudhachrisanto88@gmail.com Sapti Ayubbana ${ }^{2}$ Akademi Keperawatan Dharma Wacana Metro. Email: Sapti.ayubbana@gmail.com Yola Anjani ${ }^{3 *}$ Program Studi llmu Keperawatan, Fakultas Kedokteran, Universitas Malahayati, Bandar Lampung *Email: yolaanjani07@gmail.com 
Analisis faktor yang berhubungan dengan kemampuan pasien diabetes mellitus dalam melakukan deteksi episode hipoglikemia

Budiman, A., Khambri, D., \& Bachtiar, H. (2013). Faktor yang mempengaruhi kepatuhan berobat pasien yang diterapi dengan tamoxifen setelah operasi kanker payudara. Jurnal kesehatan andalas, 2(1), 20-24.

Fatehi-Hassanabad, Z., Chan, C. B., \& Furman, B. L. (2010). Reactive oxygen species and endothelial function in diabetes. European journal of pharmacology, 636(1-3), 8-17.

Gaol, N. T. L. (2016). Teori stres: stimulus, respons, dan transaksional. Buletin psikologi, 24(1), 1-11.

International Diabetes Federation. (2017). IDF Diabetes Atlas Eight Edition: Road map for better diabetes care. International Diabetes Federation. Diakses dari: https://www.idf.org/our-network/regionsmembers/middle-east-and-north-africa/middleeast-and-north-africa-news/98:road-map-forbetter-diabetes-care.html

Irawan, D. (2010). Prevalensi dan Faktor Risiko Kejadian Diabetes Melitus Tipe 2 di Daerah Urban Indonesia (Analisa Data Sekunder Riskesdas 2007) (Doctoral dissertation, Thesis Universitas Indonesia)

Nita, Y., Yuda, A., \& Nugraheni, G. (2012). Pengetahuan Pasien Tentang Diabetes dan Obat Antidiabetes Oral. Jurnal Farmasi Indonesia, 6(1).

Notoatmodjo, S. (2012). Promosi Kesehatan dan Perilaku Kesehatan, Jakarta: Rineka Cipta. Prince, SA (2005). Patofisiologi: Konsep klinis proses-proses penyakit.

Pribadi, T., Trismiyana, E., \& Maria, N. (2017). Pengetahuan masyarakat dengan stigmatisasi terhadap penderita tb paru di wilayah kerja puskesmas Karang Anyar Kabupaten Lampung Selatan 2017. Holistik Jurnal Kesehatan, 11(4), 265-270.
Safitri, A., Kadrianti, E., \& Ismail, I. (2014). Karakteristik Penderita Diabetes Melitus Yang Dirawat Di Ruang Baji Dakka Rsud Labuang Baji Makassar. Jurnal IImiah Kesehatan Diagnosis, 4(6), 731-737.

Shufyani, F., Wahyuni, F. S., \& Armal, K. (2017). Evaluasi faktor-faktor yang mempengaruhi kejadian hipoglikemia pada pasien diabetes mellitus tipe 2 yang menggunakan insulin. SCIENTIA: Jurnal Farmasi dan Kesehatan, 7(1), 12-19.

Sudoyo, A. W., Setiyohadi, B., Alwi, I., Simadibrata, M., \& Setiati, S. (2015). Buku ajar ilmu penyakit dalam. Edisi Ke-4. Pusat Penerbitan IImu Penyakit Dalam FKUI, Jakarta, 1218-20.

Supadi, S. (2017). Faktor-faktor yang berhubungan dengan kemampuan pasien diabetes mellitus dalam mendeteksi episode hipoglikemi di RSUD Margono Soekarjo Purwokerto. Kesmas Indonesia: Jurnal IImiah Kesehatan Masyarakat, 4(2), 119-136.

Sutawardana, J. H., \& Waluyo, A. (2016). Studi fenomenologi pengalaman penyandang diabetes melitus yang pernah mengalami episode hipoglikemia.

Tombokan, V. (2015). Faktor-faktor yang berhubungan dengan kepatuhan berobat pasien diabetes melitus pada praktek dokter keluarga di Kota Tomohon. JIKMU, 5(3).

Trisnawati, S. K., \& Setyorogo, S. (2013). Faktor risiko Kejadian diabetes melitus tipe II di puskesmas kecamatan cengkareng Jakarta Barat Tahun 2012. Jurnal IImiah Kesehatan, 5(1), 6-11.

Eka Yudha Chrisanto' DIIl Keperawatan Universitas Malahayati, Bandar Lampung. Email: yudhachrisanto88@gmail.com Sapti Ayubbana ${ }^{2}$ Akademi Keperawatan Dharma Wacana Metro. Email: Sapti.ayubbana@gmail.com Yola Anjani ${ }^{3 *}$ Program Studi llmu Keperawatan, Fakultas Kedokteran, Universitas Malahayati, Bandar Lampung

*Email: yolaanjani07@gmail.com 